\title{
Role of therapeutic plasmapheresis in ANCA-associated vasculitis
}

\author{
Giles Walters
}

Received: 14 August 2014 /Revised: 11 December 2014 / Accepted: 17 December 2014 / Published online: 19 May 2015

(C) IPNA 2014

\begin{abstract}
Plasma exchange, or plasmapheresis, is a treatment method that developed over a period of two decades and involves the removal and replacement of a patient's circulating plasma. The aim of treatment is to remove disease-associated molecules and therefore interrupt disease progression. This article summarizes the developmental history of this treatment and then looks in more detail at data on the use of plasma exchange in treating antineutrophil antibody (ANCA)-associated vasculitis. The eight randomized trials and the Cochrane Systematic Review on treating renal vasculitis are summarized to show that plasma exchange may be effective in this disease, specifically in reducing the development of end-stage kidney disease (ESKD) by approximately $40 \%$. The plasma exchange and glucocorticoid dosing in the treatment of antineutrophil cytoplasm antibody associated vasculitis (PEXIVAS) study is a currently enrolling study aiming to answer some of the outstanding questions relating to the use of this treatment in ANCA-associated vasculitis.
\end{abstract}

Keywords Plasma exchange $\cdot$ Plasmapheresis $\cdot$ ANCA . Vasculitis · Glomerulonephritis · Pulmonary haemorrhage

\section{Introduction}

This article aims to summarize available data on the use of plasma exchange in treating antineutrophil antibody

G. Walters $(\bowtie)$

Department of Renal Medicine, Canberra Hospital, Garran, ACT, Australia

e-mail: giles.walters@anu.edu.au

G. Walters

Australian National University Medical School, Canberra, ACT, Australia
(ANCA)-associated vasculitis. Immune-complex-related and other causes of vasculitis are not addressed either by this review or by the relevant trials. After a short history of the development of plasma exchange and its uses, data is summarized, including nonrandomized data for use in patients with pulmonary hemorrhage, randomized controlled trials, two systematic reviews, and the currently recruiting study Plasma exchange and glucocorticoid dosing in the treatment of anti-neutrophil cytoplasm antibody associated vasculitis (PEXIVAS). It is not intended to be an exhaustive review but, rather, to give the reader an quick overview of the history and current data relating to the topic.

\section{A short history}

Plasma exchange originated in the early 1940s in animal experiments [1]. Blood was withdrawn from the left ventricle of rabbits, centrifuged, and plasma removed. Red cells were resuspended and reinfused. The procedure was performed daily until up to $200 \mathrm{ml}$ of plasma had been removed. In 1952, regular plasma exchange was described in humans [2]. This involved the removal of $500 \mathrm{ml}$ of blood, which was allowed to stand in a refrigerator for 1 week. The serum was removed and recovered red cells were reinfused to the patient. It was a single-needle operation, with blood being drawn, followed by reinfusion of the previous week's red cells. Two patients were described, each of whom had undergone the procedure for more than 1 year. By 1960, the procedure had been somewhat streamlined, with Smolens et al. describing treating a patient with Waldenstrom's macroglobulinaemia [3]. Blood was removed, mixed with acid-citrate-dextrose, and centrifuged, and cells were returned to the patient in $2.5 \mathrm{~h}$. One patient underwent the process for 51 days, removing $62 \mathrm{U}$ of blood and 181 of plasma, demonstrating some clinical improvement in the patient. 
In the 1970s, the use of plasma exchange to improve the life of a transplant [4] was described, extending a pig-to-dog xenograft from 10 to $100 \mathrm{~min}$. In 1975, Lockwood reported treating Goodpasture's disease with plasma exchange as an adjunct to immunosuppression, demonstrating a rapid reduction in anti-glomerular-basement-membrane (GBM) antibody levels, followed by a reduction in serum creatinine $(\mathrm{SCr})$ levels [5]. This was followed by a series of four cases from Australia, also with recovery of renal function albeit shortlived for some patients [6].

In 1977, the first reports of treatment of human transplant rejection appeared, showing that some patients responded to the addition of plasma exchange to more traditional methods of treating rejection [7]. Treatment was given for 2-8 days, exchanging 3-4 1 at each treatment with saline or albumin and a unit of fresh-frozen plasma.

From 1977 to 1984, multiple reports emerged on further uses for plasma exchange in other diseases, such as pauciimmune glomerulonephritis [8], rapidly progressive glomerulonephritis (RPGN) [9], systemic lupus erythematosus (SLE) with renal involvement [10], immune-complex-mediated glomerulonephritis [11], penicillamine-associated glomerulonephritis [12], and cryoglobulinemia [13]. Reports also began to warn of the potential for infection as a complication of such treatment [14].

\section{Method: Centrifugation or filtration?}

Plasma exchange is performed using either centrifugation or filtration. Filtration was the first method to be implemented and involves the removal of all plasma contents using a membrane with large cell-retaining pores measuring $0.2-0.7 \mu \mathrm{m}$ (compared with dialysis membranes with pores measuring $10 \mathrm{~nm}$ ) [15]. All large molecules are removed by the filter, including all forms of immunoglobulin with a permeability of $80-100 \%$. It will also filter out all smaller molecules. Centrifugation also works to remove all plasma, with no upper limit to the largest molecule removed. Centrifugation machines previously had to be manually set up depending on the hematocrit of each patient, with the plasma-to-cell interface changing position in the centrifuge. More modern systems now have continuous control over the interface in a continuously flowing system. This reduces cellular loss and maximizes the efficiency of plasma removal [16]. Double-filtration plasmapheresis [17] aims to reduce the loss of the lower molecular weight molecules otherwise lost in the filtration process, returning them to the patient. Other methods have been tried, the earliest of which was electrodialysis in which the blood was passed through an electric field that drew the negatively charged larger molecules to one side, from where they were withdrawn.

\section{Nonrandomized data in pulmonary hemorrhage due to vasculitis}

The use of plasma exchange in vasculitis-associated pulmonary hemorrhage is not currently supported by randomized data. There have been several non-randomized studies, some of which have then strongly advocated its use as a standard measure. This approach tends to create difficulties for subsequent equipoise in conducting high-quality randomized trials of sufficient power. Aydin et al. reported the outcomes of 12 patients treated with immunosuppression and plasma exchange and concluded that it was efficacious and should be used in all patients with renal failure and alveolar hemorrhage [18]. In 2005, however, Yamagata et al. suggested that plasma exchange did not work, reporting on a Japanese population of 370 patients, $90 \%$ of whom had myeloperoxidase (MPO)ANCA, 53 of whom were treated with plasmapheresis [19]. Klemmer et al. [20] and Gallagher et al. [21] retrospectively reviewed 14 and 20 patients, respectively, suggesting that plasma exchange worked. Arguments to support the efficacy of plasma exchange included the reasoning that ANCA are believed to be pathogenic, with some animal experimental data to support that belief [22]; plasma exchange removes those antibodies. There are data that support the use of plasma exchange in RPGN due to vasculitis. Lung hemorrhage appears to have a similar pathogenic basis to the associated RPGN and therefore may be improved by the same treatment. These retrospective data, the logic of removing ANCA from the circulation, and the frequently severe condition of the patient with pulmonary hemorrhage puts great pressure on the physician to use plasma exchange in the absence of clear data on its benefits.

\section{Randomized data}

There are currently no randomized trial data addressing the use of plasma exchange in vasculitis in children. The largest recent study is a case series of 32 children treated with plasma exchange at the Great Ormond Street Hospital Renal Unit in London, UK from 1993 to 2003. Of these, 12 children were treated for ANCA-associated vasculitis [23]. All were treated with standard immunosuppression regimes and plasma exchange. Outcomes were generally good, but it is not possible to draw any significant conclusions about the efficacy of the plasma exchange part of their treatment.

There are eight randomized controlled studies examining the use of plasma exchange in pauci-immune-vasculitisassociated renal disease. With variable inclusion and exclusion criteria, patient populations, treatment protocols, and study quality, those trials serve as an illustration of the evolution of the field of clinical vasculitis research over the last 
30 years. Inclusion/exclusion criteria and treatment protocols are summarized in Tables 1 and 2 .

Rifle et al. published a study assessing 14 patients [24]; there was no documentation of a randomization procedure. Patient clinical presentation varied, showing some detectable antibody or complement factors on the majority of biopsies. Five of six patients treated with plasma exchange improved, whereas one of eight improved without it. The study met no major quality standards of current trial reporting.

In 1985, Mauri et al. reported on 22 patients randomized to plasma exchange or control [25]. They were diagnosed with vasculitis $(n=9)$ or idiopathic RPGN. The quality of the report was limited, with no details of randomization or allocation concealment and text that appears at times contradictory. The authors concluded that patients with an initial $\mathrm{SCr}>800 \mu \mathrm{mol} / 1$ $(9.0 \mathrm{mg} / \mathrm{dl})$ benefited from plasma exchange. In fact, their figures also suggest a benefit for those with creatinine below that value.

In 1988, Glockner et al. reported the results of 26 patients randomized to the use of plasma exchange [26]. Most were diagnosed with idiopathic RPGN, two with vasculitis, and one each with SLE, polyarteritis nodosa, and scleroderma. Immunosuppression was limited, with cyclophosphamide (CPA) used for only 2 weeks, followed by azathioprine (AZA). The report is unclear in some respects; 31 patients appear to have been recruited, but only 26 are reported. The group also rather diluted the power of their study by allowing unresponsive patients (5 of 12) at 4 weeks to cross over to use plasma exchange rather than remain at a disadvantage. Not surprisingly, this study failed to detect a difference in outcomes across groups.

In the first high-quality study, published in 1991, Pusey's group from the Hammersmith Hospital randomized 48 patients with Wegener's granulomatosis, microscopic polyangiitis, or idiopathic RPGN, 19 of whom were dialysis dependent [27]. Patients received a heavy course of immunosuppression that involved both AZA and CPA together for 2 months, then continuing AZA for maintenance therapy. The authors subdivided patients into those with $\mathrm{SCr}$ greater or less than $500 \mu \mathrm{mol} / \mathrm{l}(5.6 \mathrm{mg} / \mathrm{dl})$ or on dialysis and suggested that plasma exchange improved the chances of getting off dialysis. They published individual patient data showing that any early advantage from plasma exchange appeared to make little difference to the longer term (12 month) outcomes. Mortality at 5 years was just $<50 \%$ for both groups.

The Canadian Apheresis Study Group randomized 32 patients to receive plasma exchange or standard immunosuppression only in 1992 [28]. This was from an initial population of $>60$ patients. One patient with vasculitis was excluded. All patients were classified as having idiopathic RPGN. This was the first study to screen patients for ANCA antibodies. Of those tested, four of seven control patients and six of seven plasmaexchange patients were ANCA positive. The authors reported no difference in the number of patients recovering renal function and ceasing dialysis treatment, though results suggest that there was less dialysis at 6 months in patients on plasma exchange ( 1 of 16 vs 5 of 16 in the control group). Plasma exchange was concluded to be ineffective in these patients.

In 2002, Zauner et al. reported a trial randomizing 39 patients to standard immunosuppression with or without plasma exchange [29]. Some patients had Couser type II and III GN, suggestive of immunoglobulin deposition on renal biopsies. The report did not indicate that plasma exchange was effective.

In 2007, the European Vasculitis Study Group published the first large, high-quality, randomized trial, the MEPEX study, to investigate the use of plasma exchange in $137 \mathrm{pa}-$ tients with ANCA-associated vasculitis and severe renal failure $[\mathrm{SCr}>500 \mu \mathrm{M}(5.65 \mathrm{mg} / \mathrm{dl})]$ [30]. Patients were also treated orally with prednisolone and CPA. The comparator treatment was pulse methylprednisolone (MP). The primary outcome was dialysis independence at 3 months, with an increase by $20 \%$ in the number of patients alive and off dialysis (49-69\%). At 1 year, risk reduction in progression to end-stage kidney disease (ESKD) was $24 \%$ for plasma exchange compared with pulse MP.

In 2010, Szpirt et al. published an interesting study of 32 patients recruited between 1991 and 1995 and randomized in a two-by-two factorial design to either plasma exchange or control and in a second randomization to the use of cyclosporin at 3 months as compared with continuing CPA for a further 9 months [31]. Results were reported to 5 years of follow-up, perhaps partly explaining the long gestation to study publication. Renal survival was significantly improved by plasma exchange at all time points without any impact on other morbidity or mortality.

\section{Systematic review and meta-analysis}

The results of these studies are combined in our Cochrane Systematic Review [32], which is being updated at the time of this writing. No study prior to the MEPEX study in 2007 [30] showed significance in any major outcomes. In performing the meta-analysis, varying patient characteristics (Table 1), treatment protocols (Table 2), and trial quality were considered. However, results show a low level of heterogeneity, suggesting that the overall result is likely to be valid.

Plasma exchange significantly reduced the risk of ESKD at 3 months [2 studies; relative risk (RR) 0.43 ; $95 \%$ confidence interval (CI) $0.23-0.78) ; P=0.006$; number needed to treat $(\mathrm{NNT})=5$ ] and 12 months [5 studies; RR 0.45; $95 \%$ CI 0.29 $0.72 ; P=0.008 ; \mathrm{NNT}=5 ; \mathrm{I}^{2}=0 \%$ ] posttreatment (Fig. 1). Mortality appears to be unchanged. There were no other demonstrable differences between groups in terms of renal function or adverse events. Our conclusion in this part of the review is that plasma exchange reduces the risk of dialysis- 


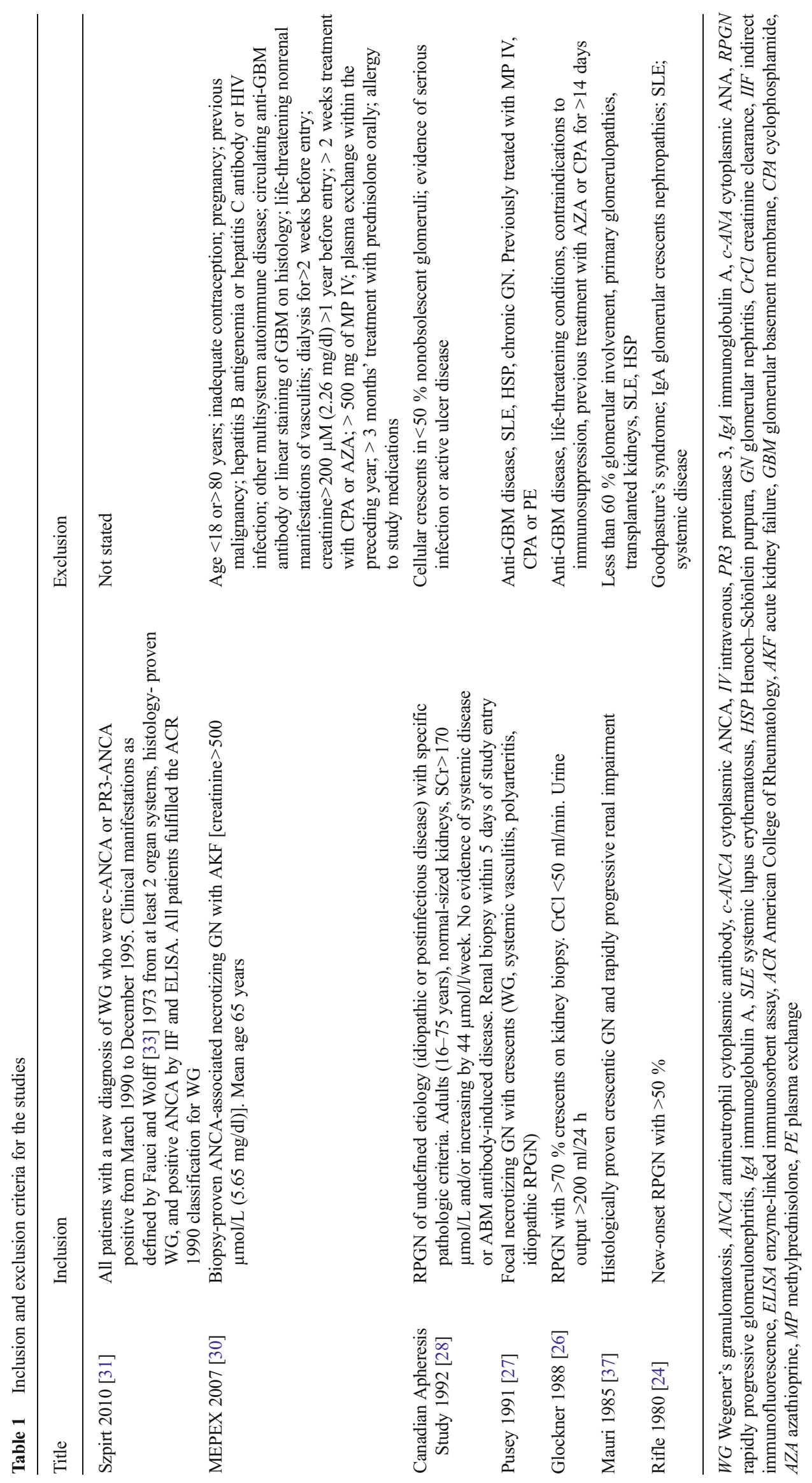


Table 2 Study interventions

\begin{tabular}{|c|c|}
\hline Title & Interventions \\
\hline Szpirt 2010 & $\begin{array}{l}\text { Standard induction immunosuppression for all patients: } \\
\text { Prednisolone } 80 \mathrm{mg} \text { daily for } 3 \text { weeks tapered to } 5 \mathrm{mg} \text { then stopped after } 9 \text { months. CPA } 1.5 \mathrm{mg} / \mathrm{kg} \text { daily for } 3 \text { months } \\
\text { PE group: } \\
\text { Six sessions of } 4 \mathrm{~L} \text { plasma exchange with } 3 \% \text { albumin in Ringer's lactate solution replacement on alternate days. } \\
\text { Performed using Gambro F-1000 filters. If c-ANCA titers }>320 \text { or PR3-ANCA }>25 \mathrm{U} / \mathrm{ml} \text { on ELISA after } 6 \text { sessions, } \\
\text { the additional } 3-6 \text { sessions are performed. } \\
\text { After } 3 \text { months of induction treatment, all patients underwent a second randomization to either continue CPA or to } \\
\text { change to CyA for } 9 \text { months. Dose initiated: } 5 \mathrm{mg} / \mathrm{kg} \text { daily with trough levels } 150-200 \mu \mathrm{mol} / \mathrm{L}\end{array}$ \\
\hline MEPEX 2007 & $\begin{array}{l}\text { Control group: } \\
\text { Cyclophosphamide } 2.5 \mathrm{mg} / \mathrm{kg} \text { orally per day, reduced to } 1.5 \mathrm{mg} / \mathrm{kg} \text { per day at } 3 \text { months ending at } 6 \text { months. Azathioprine } \\
2 \mathrm{mg} / \mathrm{kg} \text { per day commenced at } 6 \text { months.Prednisolone tapered from } 1 \mathrm{mg} / \mathrm{kg} \text { per day orally at entry to } 0.25 \mathrm{mg} / \mathrm{kg} \text { per day } \\
\text { by } 10 \text { weeks, } 15 \mathrm{mg} \text { per day at } 3 \text { months, and } 10 \mathrm{mg} \text { per day from } 5 \text { to } 12 \mathrm{months}\end{array}$ \\
\hline $\begin{array}{l}\text { Canadian Apheresis } \\
\text { Study } 1992\end{array}$ & $\begin{array}{l}\text { Control group: } \\
\text { Immunosuppression: MP IV } 10 \mathrm{mg} / \mathrm{kg} / \text { day for } 3 \text { days, followed by prednisone } 1.4 \mathrm{mg} / \mathrm{kg} / \text { day for next } 4 \text { days, } \\
\text { and then tapered to } 1 \mathrm{mg} / \mathrm{kg} / \text { day over } 2 \text { weeks; } 0.35 \mathrm{mg} / \mathrm{kg} / \text { day at } 1 \text { month and } 025 \mathrm{mg} / \mathrm{kg} / \text { day at } 2 \text { months. } \\
\text { AZA } 1.5-3.0 \mathrm{mg} / \mathrm{kg} / \text { day, with dose adjustment as necessary to ensure neutrophil count of } \geq 2.0 \mathrm{109} / \mathrm{L} \\
\text { Study duration } 12 \mathrm{months} \text { follow-up } \\
\text { PE group: } \\
\text { Immunosuppression: as for control group } \\
\text { PE: at least } 10 \text { plasma exchange treatments within } 16 \text { days of study entry; } 1 \text { plasma volume with complete } \\
\text { replacement using } 5 \% \text { albumin }+ \text { crystalloid }\end{array}$ \\
\hline Pusey 1991 & $\begin{array}{l}\text { Control group: } \\
\text { Induction therapy, } 8 \text { weeks of: } \\
60 \mathrm{mg} / \text { day prednisolone, reducing by } 15 \mathrm{mg} \text { at weekly intervals to } 30 \mathrm{mg} / \text { day, then } 5 \mathrm{mg} \text { at weekly intervals to } \\
20 \mathrm{mg} / \text { day, and then more slowly, as clinically indicated. CPA } 3 \mathrm{mg} / \mathrm{kg} / \mathrm{day} \text { or } 2 \mathrm{mg} / \mathrm{kg} / \text { day for those } \\
>55 \mathrm{years} \text {. AZA } 1 \mathrm{mg} / \mathrm{kg} / \text { day or no AZA for those }>55 \text { years } \\
\text { Maintenance therapy: } \\
\text { CPA stopped after } 8 \text { weeks in those with remission and AZA increased to } 2-3 \mathrm{mg} / \mathrm{kg} / \text { day, together with tapering } \\
\text { doses of prednisolone } \\
\text { PE group: } \\
\text { Induction/maintenance therapy: as for control group. PE: } 5 \times 4 \mathrm{~L} \text { exchanges of } 5 \% \text { albumin (plasma protein } \\
\text { fraction) within first week. Two units of fresh-frozen plasma given at end of exchange. Total number of } \\
\text { exchanges determined by clinical response } \\
\text { Study duration: treatment for } 1 \text { year, after which attempts to discontinue }\end{array}$ \\
\hline Glockner 1988 & $\begin{array}{l}\text { Control group: } \\
\text { No PE. Standard Immunosuppression } \\
\text { All patients received immunosuppression in the form of CPA } 3 \mathrm{mg} / \mathrm{kg} / \text { day plus AZA } 1 \mathrm{mg} / \mathrm{kg} / \text { day for } 1 \text { week, } \\
\text { then AZA } 2 \mathrm{mg} / \mathrm{kg} / \text { day; 6-MP } 1.5 \mathrm{mg} / \mathrm{kg} / \text { day for } 14 \text { days, reducing in } 4-\mathrm{mg} / \text { day steps to maintenance } 8 \mathrm{mg} / \text { day. } \\
\text { Patients with WG }(n=2) \text { did not receive AZA, only CPA } 3 \mathrm{mg} / \mathrm{kg} / \text { day for entire study period } \\
\text { PE group: } \\
\text { Nine } 50 \mathrm{ml} / \mathrm{kg} \text { plasma exchange over } 4 \text { weeks replaced with } 3-5 \% \text { albumin solution. Also standard immunosuppression } \\
\text { Study duration: 6-month follow-up }\end{array}$ \\
\hline Mauri 1985 & $\begin{array}{l}\text { Control group: } \\
\text { CPA } 2 \mathrm{mg} / \mathrm{kg} / \text { day and prednisolone } 1 \mathrm{mg} / \mathrm{kg} / \text { day. Doses reduced to half after } 8 \text { weeks. Prednisolone dose tapered } \\
\text { progressively. CPA dose reduced to } 0.5 \mathrm{mg} / \mathrm{kg} / \text { day after } 2 \text { months then stopped after month } 4 \\
\text { PE group: } \\
\text { PE alternate days for } 6 \text { treatments. Exchanges of at least } 3.5 \mathrm{~L} \text { replaced with } 3.5 \% \text { albumin and } 2 \mathrm{U} \text { FFP. } \\
\text { Immunosuppression as for control patients } \\
\text { Study duration: } 12 \text {-month follow-up }\end{array}$ \\
\hline Rifle 1980 & $\begin{array}{l}\text { Control group: } \\
\text { Immunosuppression: Pulse MP, IV }(15 \mathrm{mg} / \mathrm{kg} / \text { day for } 3 \text { days, tapered to } 15 \mathrm{mg} / \text { day for } 3 \text { days, then } 3 \text { new pulses, } \\
\text { then } 15 \mathrm{mg} / \text { day for } 7 \text { weeks. CPA } 2-3 \mathrm{mg} / \mathrm{kg} / \text { day for } 2 \text { months. Calcium heparinate } 9 \text { days after kidney biopsy } \\
\text { for study duration } \\
\text { PE group: } \\
\text { Immunosuppression as per control group plus PE. Five sessions during } 5 \text { successive days, then } 3 \text { sessions/week until } \\
15 \text { days after SCr reached plateau. Treatment could not exceed } 2 \text { months. } 150 \% \text { plasma volume exchanged for } \\
\text { albumin and saline solution at each session } \\
\text { Study duration: } 2 \text { months }\end{array}$ \\
\hline
\end{tabular}

$C P A$ cyclophosphamide, $W G$ Wegener's granulomatosis, $A N C A$ antineutrophil cytoplasmic antibody, $c-A N C A$ cytoplasmic ANCA, $I V$ intravenous, $P R 3$ proteinase 3, IgA immunoglobulin A, ELISA enzyme-linked immunosorbent assay, $A Z A$ azathioprine, $M P$ methylprednisolone, $P E$ plasma exchange, $S C r$ serum creatinine, $F F P$ fresh-frozen plasma, $M E P E X$ randomized trial of plasma exchange or high-dosage methylprednisolone as adjunction theraphy for severe renal vaculitis 


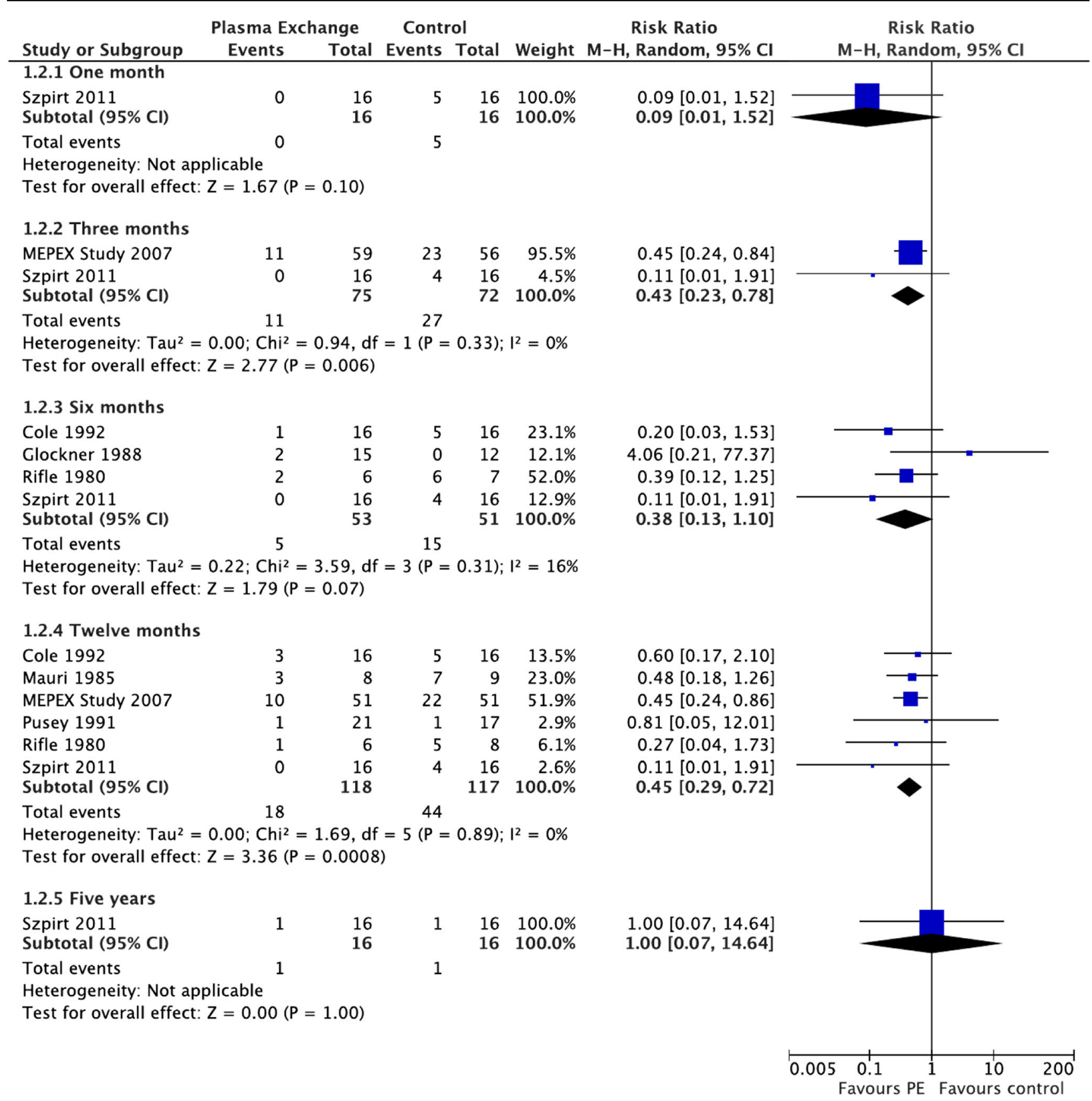

Fig. 1 Effect of plasma exchange on the requirement for dialysis over time

dependent renal failure in patients with severe renal failure. The patient populations included in the studies do not permit a wider application to those with less severe renal failure, since few such patients were included.

Walsh et al. published a similar systematic review as the basis for establishing the PEXIVAS study [34]. Their conclusions were very similar to ours, but they added the rather contentious step of suggesting a composite outcome of dialysis-dependent renal failure or death. The argument is extended in the long-term follow-up of the MEPEX study published recently [35]. The group includes an analysis of the effect of plasma exchange on ESKD, with death as a competing risk. The study shows that the effect of plasma exchange occurs early and is maintained for $>5$ years, with no evidence of a reduction over time. However, the statistical significance of results diminishes over time, and the result is therefore labeled as insignificant. Considering that the study was not designed for this length of follow-up and that $20 \%$ of patients in the plasma exchange limb were lost to follow-up, the result is remarkable and strongly suggests that the initial benefit of plasma exchange is likely to persist over time. Our problem with the composite outcome 
is that outcomes are demonstrably contradictory. For most studies, a composite outcome of mortality and ESKD increases study sensitivity into the effect of a treatment; however, in this case, results of available studies suggest a strong effect on dialysis dependence but no effect on mortality. Combining these two outcomes into a single composite outcome of "hard end points" reduces the sensitivity of available data, resulting in statistical insignificance. This leads the study group to argue that there is no significant data to support the use of plasma exchange in vasculitis.

\section{The future: the PEXIVAS study}

Current data support the use of plasma exchange in a highly restricted group of patients in order to reduce the incidence of ESKD. The PEXIVAS study is a large, multinational, randomized study recruiting patients with severe vasculitis (documented renal involvement or pulmonary hemorrhage) in Europe, USA, Canada, Japan, Australia, and New Zealand [36]. Patients are randomized in a factorial design, first to the use of plasma exchange, then between standard- dose or halfdose glucocorticoid regimens. Aiming for 500 patients, recruitment began in 2010 and was on target at time of this writing at $\sim 350$. The study aims to answer some of the outstanding questions relating to the use of plasma exchange: Does it work for patients with less severe renal failure? Can we demonstrate a reduction in mortality with a larger and higher-quality study? Does it work in patients with pulmonary hemorrhage?

There has been some discussion over inclusion criteria for the study. Patients with renal failure and $\mathrm{SCr} \geq 500 \mu \mathrm{M}$ $(5.65 \mathrm{mg} / \mathrm{dl})$ are eligible. Some physicians feel that inclusion of such patients is unnecessary, since there is some moderately clear data that plasma exchange is effective in this group. This will inevitably reduce the number of patients with severe renal failure that are recruited, which will ultimately increase the relative number of patients with a lesser degree of renal failure. Hopefully, this situation will make any data on this subgroup more informative and more likely to prodce a definitive answer.

The inclusion of patients with pulmonary hemorrhage is also a concern for many physicians. When faced with a patient with severe ventilator-dependent pulmonary hemorrhage, many feel obliged to treat the patient with plasma exchange rather than to randomize them in PEXIVAS. The result of this will most likely mean that mild to moderate pulmonary hemorrhage features more strongly in the patient population. Whilst this may work against the likelihood of a positive treatment effect in ventilated patients, a positive effect is likely to have greater external validity and apply to a wider cohort of patients.

\section{Key summary points}

- Plasma exchange or plasmapheresis works by removing the circulating plasma volume of a patient.

- Both centrifugation and filtration remove most molecules in plasma regardless of size.

- Current data suggest that plasma exchange reduces the risk of end-stage kidney disease in treated patients with severe renal vasculitis by $\sim 40 \%$.

- The PEXIVAS study is randomizing $>500$ patients to clarify the role of plasma exchange in ANCA-associated vasculitis in patients with renal failure and/or pulmonary hemorrhage.

\section{Conclusion}

Current data support the use of plasma exchange in treating ANCA-associated vasculitis that results in severe renal failure, resulting in a reduced incidence of dialysis dependence. There is currently no other clear role for such treatment. Severe pulmonary hemorrhage is treated with plasma exchange on the basis of a pragmatic approach to retrospective data. The PEXIVAS study promises to deliver high-quality data on the use of plasma exchange in a broader population of patients with less severe renal failure as well as the first randomized data on treating pulmonary hemorrhage.

The gradual evolution of study and data quality over the last 30 years reflects the development of increasingly large organized trial networks in Europe, USA, Canada, and, more recently, Australia. Hopefully, this trend will continue, with current networks continuing to broaden their support base and working to improve their collaborative links with other networks, thus creating large, high-quality, investigator-driven, collaborative studies such as PEXIVAS the norm instead of the rare exception in nephrology.

\section{Multiple-choice questions (answers are provided following the reference list)}

1. True or false: Plasma exchange is a well-proven treatment for vasculitis-associated pulmonary hemorrhage.

2. True or false: Plasma exchange removes IgG selectively from the circulation.

3. True or false: Plasma exchange has been shown to reduce the incidence of ESKD in severe, acute, ANCAassociated vasculitis.

4. True or false: Plasma exchange has been shown to reduce mortality when used in treating severe acute ANCAassociated vasculitis.

5. True or false: Composite study endpoints always increase the sensitivity of a study. 


\section{References}

1. Cannon PR, Chase WE, Wissler RW (1943) The relationship of the protein-reserves to antibody production. J Immunol 47:133

2. Adams WS, Blahd WH, Bassett SH (1952) A method of human plasmapheresis. Proc Soc Exp Biol Med Soc Exp Biol Med N Y N 80:377-379

3. Smolens J, Stokes J Jr, Vogt AB (1957) Human plasmapheresis and its effect on antibodies. J Immunol 79:434-439

4. Merkel FK, Bier M, Beavers CD, Merriman WG, Wilson C, Starzl TE (1971) Modification of xenograft response by selective plasmapheresis. Transplant Proc 3:534-537

5. Lockwood CM, Boulton-Jones JM, Lowenthal RM, Simpson IJ, Peters DK (1975) Recovery from Goodpasture's syndrome after immunosuppressive treatment and plasmapheresis. Br Med J 2: 252-254

6. Walker RG, d'Apice AJ, Becker GJ, Kincaid-Smith P, Craswell PW (1977) Plasmapheresis in Goodpasture's syndrome with renal failure. Med J Aust 1:875-879

7. Cardella CJ, Sutton D, Uldall PR, DeVeber GA (1977) Intensive plasma exchange and renal transplant rejection. Lancet 309:264

8. Becker GJ, d' Apice AJ, Walker RG, Kincaid-Smith P (1977) Plasmapheresis in the treatment of glomerulonephritis. Med J Aust 2:693-696

9. Saal SD, Gordon B, Evans E, Stack J, Suthanthiran M (1981) Plasmapheresis in the prevention and treatment of rapidly progressive renal disease. Clin Exp Dial Apheresis 5:65-78

10. Błaszczyk M, Chorzelski T, Daszyński J, Gaczkowski A, Jabłońska S, Beutner EH (1981) Plasmapheresis in the treatment of systemic lupus erythematosus. Arch Immunol Ther Exp (Warsz) 29:769-772

11. Lockwood CM, Pinching AJ, Sweny P, Rees AJ, Pussell B, Uff J, Peters DK (1977) Plasma exchange and immunosuppression in the treatment of fulminating immune-complex crescentic nephritis. Lancet 1:63-67

12. Gavaghan TE, McNaught PJ, Ralston M, Hayes JM (1981) Penicillamine-induced "Goodpasture's syndrome": successful treatment of a fulminant case. Aust N Z J Med 11:261-265

13. Geltner D, Kohn RW, Gorevic P, Franklin EC (1981) The effect of combination therapy (steroids, immunosuppressives, and plasmapheresis) on 5 mixed cryoglobulinemia patients with renal, neurologic, and vascular involvement. Arthritis Rheum 24:1121-1127

14. Wing EJ, Bruns FJ, Fraley DS, Segel DP, Adler S (1980) Infectious complications with plasmapheresis in rapidly progressive glomerulonephritis. JAMA 244:2423-2426

15. Sueoka A (1997) Present status of apheresis technologies: Part 1. Membrane plasma separator. Ther Apher 1:42-48

16. Tormey CA, Peddinghaus ME, Erickson M, King KE, Cushing MM, Bill J, Goodrich T, Snyder EL (2010) Improved plasma removal efficiency for therapeutic plasma exchange using a new apheresis platform. Transfusion 50:471-477

17. Higgins R, Lowe D, Hathaway M, Lam FT, Kashi H, Tan LC, Imray C, Fletcher S, Chen K, Krishnan N, Hamer R, Zehnder D, Briggs D (2010) Double filtration plasmapheresis in antibody-incompatible kidney transplantation. Ther Apher Dial 14:392-399

18. Aydin Z, Gursu M, Karadag S, Uzun S, Tatli E, Sumnu A, Ozturk S, Kazancioglu R (2011) Role of plasmapheresis performed in hemodialysis units for the treatment of anti-neutrophilic cytoplasmic antibody-associated systemic vasculitides. Ther Apher Dial 15:493498
19. Yamagata K, Hirayama K, Mase K, Yamaguchi N, Kobayashi M, Takahashi H, Koyama A (2005) Apheresis for MPO-ANCAassociated RPGN-indications and efficacy: lessons learned from Japan nationwide survey of RPGN. J Clin Apher 20:244-251

20. Klemmer PJ, Chalermskulrat W, Reif MS, Hogan SL, Henke DC, Falk RJ (2003) Plasmapheresis therapy for diffuse alveolar hemorrhage in patients with small-vessel vasculitis. Am J Kidney Dis 42: $1149-1153$

21. Gallagher H, Kwan JTC, Jayne DRW (2002) Pulmonary renal syndrome: a 4-year, single-center experience. Am J Kidney Dis 39:4247

22. Xiao H, Heeringa P, Hu P, Liu Z, Zhao M, Aratani Y, Maeda N, Falk RJ, Jennette JC (2002) Antineutrophil cytoplasmic autoantibodies specific for myeloperoxidase cause glomerulonephritis and vasculitis in mice. J Clin Invest 110:955-963

23. Wright E, Dillon MJ, Tullus K (2006) Childhood vasculitis and plasma exchange. Eur J Pediatr 166:145-151

24. Rifle G, Chalopin JM, Zech P, Deteix P, Ducret F, Vialtel P, Cordonnier D (1981) Treatment of idiopathic acute crescentic glomerulonephritis by immunodepression and plasma-exchanges. A prospective randomised study. Proc Eur Dial Transpl Assoc 18: 493-502

25. Mauri JM, Gonzalez MT, Poveda R, Seron D, Torras J, Andujar J, Andres E, Alsina J (1985) Therapeutic plasma exchange in the treatment of rapidly progressive glomerulonephritis. Plasma Ther Transf Technol 6:587-591

26. Glöckner WM, Sieberth HG, Wichmann HE, Backes E, Bambauer R, Boesken WH, Bohle A, Daul A, Graben N, Keller F (1988) Plasma exchange and immunosuppression in rapidly progressive glomerulonephritis: a controlled, multicenter study. Clin Nephrol 29:1-8

27. Pusey CD, Rees AJ, Evans DJ, Peters DK, Lockwood CM (1991) Plasma exchange in focal necrotizing glomerulonephritis without anti-GBM antibodies. Kidney Int 40:757-763

28. Cole E, Cattran D, Magil A, Greenwood C, Churchill D, Sutton D, Clark W, Morrin P, Posen G, Bernstein K (1992) A prospective randomized trial of plasma exchange as additive therapy in idiopathic crescentic glomerulonephritis. The Canadian Apheresis Study Group. Am J Kidney Dis 20:261-269

29. Zäuner I, Bach D, Braun N, Krämer BK, Fünfstück R, Helmchen U, Schollmeyer P, Böhler J (2002) Predictive value of initial histology and effect of plasmapheresis on long-term prognosis of rapidly progressive glomerulonephritis. Am J Kidney Dis 39:28-35

30. Jayne DRW, Gaskin G, Rasmussen N, Abramowicz D, Ferrario F, Guillevin L, Mirapeix E, Savage COS, Sinico RA, Stegeman CA, Westman KW, van der Woude FJ, de Lind van Wijngaarden RAF, Pusey CD (2007) Randomized trial of plasma exchange or highdosage methylprednisolone as adjunctive therapy for severe renal vasculitis. J Am Soc Nephrol 18:2180-2188

31. Szpirt WM, Heaf JG, Petersen J (2011) Plasma exchange for induction and cyclosporine A for maintenance of remission in Wegener's granulomatosis - a clinical randomized controlled trial. Nephrol Dial Transplant 26:206-213

32. Walters G, Willis NS, Craig JC (2008) Interventions for renal vasculitis in adults. Cochrane Database Syst Rev 3, CD003232

33. Fauci AS, Wolff SM (1973) Wegener's granulomatosis: studies in eighteen patients and a review of the literature. Medicine 52: $535-561$

34. Walsh M, Catapano F, Szpirt W, Thorlund K, Bruchfeld A, Guillevin L, Haubitz M, Merkel PA, Peh CA, Pusey C, Jayne D (2011) Plasma Exchange for Renal Vasculitis and Idiopathic 
Rapidly Progressive Glomerulonephritis: A Meta-analysis. Am J Kidney Dis 57:566-574

35. Walsh M, Casian A, Flossmann O, Westman K, Höglund P, Pusey C, Jayne DRW (2013) Longterm follow-up of patients with severe ANCA-associated vasculitis comparing plasma exchange to intravenous methylprednisolone treatment is unclear. Kidney Int 84:397402

36. Walsh M, Merkel PA, Peh CA, Szpirt W, Guillevin L, Pusey CD, De Zoysa J, Ives N, Clark WF, Quillen K, Winters JL, Wheatley K, Jayne D, Investigators PEXIVAS (2013) Plasma exchange and glucocorticoid dosing in the treatment of anti-neutrophil cytoplasm antibody associated vasculitis (PEXIVAS): protocol for a randomized controlled trial. Trials 14:73
37. Mauri JM, Gonzalez MT, Poveda R (1985) Therapeutic plasma exchange in the treatment of rapidly progressive glomerulonphritis. Plasma Ther Transfus Technol 6:587-591

\section{Multiple-choice answers}

1. False

2. False

3. True

4. False

5. False 